\title{
LAPSEN KUULEMISESTA KIRJOITTAMINEN OLOSUHDESELVITYKSISSÄ ${ }^{1}$
}

Aino Kääriäinen: VTT, dosentti, yliopistonlehtori, Helsingin yliopisto

aino.kaariainen@helsinki.fi

Janus vol. 27 (4) 2019, 379-394

Tiivistelmä

\section{() 8 ?}

VERTAISARVIOITU
KOLLGGALT GRANSKAD
PEER-REVIEWED
wwww.tsv.tiftunnus

Artikkelissa analysoidaan sosiaalitoimen käräjäoikeuksien pyynnöstä laatimia selvityksiä lapsen olosuhteista vanhempien huoltoriidan ratkaisemiseksi. Kiinnostus kohdistetaan siihen, millä tavoin ammattilaiset muodostavat, tuottavat tai muotoilevat lapsen käsityksï vanhempien huoltoriidassa. Aineisto käsittää 56 sosiaalitoimen laatimaa olosuhdeselvitystä 45 tapauksesta viidestä eri käräjäoikeudesta vuodelta 2011. Analyysiä varten aineistosta on erotettu lasten kuulemisen kuvaukset, joita analysoidaan erotellen sosiaalityöntekijöiden tapoja rakentaa lapsen kuulemisen kuvauksia vanhempien huoltoriidassa. Olosuhdeselvitysasiakirjoissa lapsen mielipiteen kirjoittamisessa käytettiin lapsen toiminnan havainnointia, tekstiin rakennettuja dialogeja sekä lojaliteettiristiriidan ja turvattomuuden kokemusten havainnollistamista. Lapsen äänen kirjoittaminen asiakirjaan on vastuullinen tehtävä. Kirjoittaja joutuu tasapainoilemaan autenttisuuden, eettisyyden ja seurauksellisuuden välillä.

\section{JOHDANTO}

Suuri osa vanhemmista sopii parisuhteen päättyessä yhteisymmärryksessä lapsensa asumiseen, elatukseen ja tapaamisiin liittyvistä asioista. Sosiaalitoimi vahvisti vuonna 2017 yhteensä 48419 tällaista sopimusta (SVT 2017). Mikäli vanhemmat eivät pääse yhteisymmärrykseen lapsen asioiden järjestämisestä, toinen tai molemmat vanhemmat voivat hakea ratkaisua käräjäoikeudesta. Tällöinkin vanhemmat saattavat päätyä prosessin kuluessa riidattomasti ratkaisuun tai päätös on sellainen, ettei toinen vanhempi sitä riitauta. Tässä artikkelissa syvennytään tilanteisiin, joissa vanhemmat eivät pääse yhteisymmärrykseen lapsen asioiden järjestämisestä ja sosiaalitoimi tulee mukaan prosessiin selvittämään lapsen tilannetta ja käsityksiä asiasta.

Riitaisia huolto- ja tapaamisasioita oli käräjäoikeuksissa vuosina 2015-2017 yhteensä 3964, mikä on noin 1300 tapausta vuodessa (HE 88/2018). Huoltoriidalla tarkoitan tässä artikkelissa tilannetta, jossa vanhempi on tehnyt hakemuksen käräjäoikeuteen lapsen huollon, elatuksen tai tapaamisoikeuden ratkaisemiseksi ja tilanteesta on pyydetty sosiaalitoimelta vanhempien ja lapsen olosuhteita koskeva selvitys (Lapsenhuoltolaki, LHL, \& 16). Vuonna 2017 selvityksiä pyydettiin yhteensä 1 128 tapauksesta (SVT 2017). Pahimmillaan lasta koskevat tuomioistuinkäsittelyt olosuhdeselvityksineen ja täytäntöönpanoprosesseineen voivat venyä 
vuosia kestäviksi konfliktoituneiksi tapaamis- ja huoltoriidoiksi (esim. Auvinen 2006).

Lapsen asema länsimaisen yhteiskunnan jäsenenä on muuttunut paljon 1990-luvulta alkaen. Lapsuutta ei enää käsitetä vain aikuisuutta edeltävänä kehitysvaiheena, vaan lapsi nähdään myös yhteiskunnan jäsenenä siinä missä aikuisetkin. Lapsilla on samat perustuslailliset oikeudet tulla kohdelluiksi tasa-arvoisesti yksilöinä ja vaikuttaa itseään koskeviin asioihin kehitystään vastaavalla tavalla (PL 6. luku, \2). Suomi vahvisti YK:n lapsen oikeuksien sopimuksen vuonna 1991, mikä asetti viranomaisille ja tuomioistuimille velvollisuuden toimia lasta koskevia asioita käsitellessään lapsen osallisuutta edesauttaen. Tämä tarkoittaa muun muassa, että lapselle on annettava mahdollisuus tulla kuulluksi häntä koskevissa oikeudellisissa ja hallinnollisissa asioissa ikänsä ja kehitystasonsa mukaisesti (LOS, 12. art.).

Kuulluksi tuleminen omissa asioissaan on lapsen perusoikeus ja viranomaisen tehtävä on taata tämän perusoikeuden toteutuminen. Oikeudenkäynnissä lasta ei kuulla henkilökohtaisesti, vaan oikeus pyytää sosiaalitoimelta olosuhdeselvityksen, jonka oleellisena osana on lapsen tapaamisiin perustuva mielipiteen selvittäminen. Lapsen ääni tulee siis esiin välitettynä sosiaalityöntekijöiden kirjoittamissa selvitysasiakirjoissa. Lähestymistavaltaan tämä artikkeli kiinnittyy lapsuudentutkimuksen suuntaukseen, joka on kriittisesti tarkastellut lapsen äänen kuulemista palvelukäytännöissä (esim. Alanen 2009; Hyvärinen \& Pösö 2018; Nikupeteri \& Laitinen 2017; Skjørten 2013).
Artikkelissa analysoidaan olosuhdeselvitysprosessissa lapsen olosuhteiden, kuulemisen ja mielipiteen selvittämisen yhteydessä kirjoitettuja lapsia koskevia kuvauksia tilanteessa, jossa vanhemmat riitelevät lapsen huollosta ja tapaamisoikeudesta. Tutkimustehtävänäni on tehdä näkyväksi sitä, millä tavoin ammattilaiset muodostavat, tuottavat tai muotoilevat lapsen käsityksiä vanhempien huoltoriidassa. Asiakirjojen kirjoittaminen ei ole vain tiedon kokoamista, vaan mitä suurimmassa määrin tiedon rakentamista (Brandt ym. 2011). Kirjoittamista ohjaavat kysytyt kysymykset ja työntekijän tavat kirjoittaa tekstejä (Kääriäinen 2016). Tekstit ovat aina kirjoittajiensa tekemiä tulkintoja, eikä niistä voi lukea kuin sen, mitä niihin on kirjoitettu (Ricœur 2000, 119-120). Koska lapsen kuulemista ja mielipidettä käsittelevät asiakirjat ovat olennaisia tuomioistuimen päätöksenteossa, niiden laatu sekä sisältö ovat merkityksellisiä. Suomessa tutkimusta olosuhdeselvitysasiakirjoista on tehty vähän ja erityisesti lasten mielipiteen selvittämisestä puuttuu tutkimustietoa (esim. Auvinen 2006, 148). Asiakirjat luovat tiedollisen perustan päätöksenteolle. Huoltoriidan osapuolien elämäntilanteesta laadittujen asiakirjojen avulla muodostetaan ymmärrystä ja tallennetaan tietoa, joka suuntaa toimintaa ja ratkaisuja. Tämän vuoksi asiakirjatekstien tutkiminen on tärkeää.

\section{LAPSEN MIELIPITEEN SELVITTÄMINEN HUOLTORIDASSA}

Lapsen osallisuuden vahvistaminen näkyy vahvana trendinä poliittisissa linjauksissa. Lapsia ja perheitä koskevia sopimuksia sekä toimintaperiaatteita muokataan esimerkiksi valtakunnal- 
lisessa Lasten ja perheiden palvelujen kehittämishankkeessa (esim. Alatalo ym. 2017) ja lapsen huoltolain uudistamistyössä (Oikeusministeriö 2017, 9-10; HE 88/2018). Lainsäädännöllisten linjausten ja työkäytäntöjen muuttamisen välillä on kuitenkin kurottavaa. Esimerkiksi Sanna Koulun (2014) mukaan lapsen oikeudet näkyvät juridisissa ratkaisuissa heikosti. Hänen mukaansa lapsen hyvinvointi ei tosiasiassa ole niin ensisijainen ja keskeinen kuin mitä oikeuden itseymmärryksessä yleensä ajatellaan. (Mt., 401.) Tutkimuksessa on löydetty viitteitä myös siitä, että erotilanteessa lastensuojelun sosiaalityöntekijöiden työskentely keskittyy vanhempien riitojen lieventämiseen ja yhteistyövanhemmuuden tavoitteluun lapsen oikeuksien vahvistamisen sijasta (Cukurs 2018).

Lapsen huoltoa ja tapaamisoikeutta koskevaa asiaa käsitellessään käräjäoikeuden on hankittava selvitys sen kunnan sosiaalilautakunnalta, missä lapsella, lapsen vanhemmilla, huoltajalla ja huoltajaksi esitetyllä on asuin- tai olinpaikka. Selvitystä ei tarvitse hankkia, mikäli se on ilmeisen tarpeetonta. (LHL 361/1983, 16. \$, 1 mom.) Sosiaalitoimella on selvityksen tekijänä erityisasema siksi, että sillä on oikeus hankkia ja välittää sellaista lapsen edun tai yleisen tai yksityisen edun vuoksi välttämätöntä salassa pidettävää tietoa, jota ei sosiaalihuollon asiakkaan asemasta ja oikeuksista annetun lain (SHAL 18 \$, 1. mom; 19 \$, 2-4. mom) mukaan saisi muuton ilmaista (Auvinen 2002; LHL 16 S, 3 mom). Selvityksen laatimiseen on annettu käytännön ohjeita työkäytäntöjen yhtenäistämiseksi (esim. Auvinen 2002; Lastensuojelun käsikirja THL; Taskinen 2001). Viime- aikaisten tutkimusten (Hautanen 2010, 179; Kääriäinen 2015; Simon \& Stahl 2014) mukaan olosuhdeselvitykset ovat rakenteeltaan keskenään hyvin samankaltaisia, mutta niiden sisällöllisessä tyylissä ja laajuudessa on vaihtelua, mikä ei selity pelkästään tapausten erityispiirteillä (Kääriäinen 2015, 385-389).

Lapsen mielipiteeseen vaikuttaa moni tekijä, eikä vähiten se, että lapsi on lojaali vanhemmilleen. Anna-Maija Castrén $(2018,175)$ huomauttaa, että lapsen tila määritellä uudelleen suhde äitiin ja isään vanhempien eron jälkeen on ahdas, sillä lapsen kumpaakin vanhempaa kohtaan tuntema lojaalius rajaa sitä tiukasti. Risto Karttunen (2010, 162) muistuttaa, että vanhempiensa eroriidan keskellä lapsella on kokonaan oma kokemusmaailmansa ja omat toiveensa. Lapset havainnoivat tilanteita omasta maailmastaan käsin. Mikäli vanhemmat eivät keskustele riittävästi lastensa kanssa eroprosessista, lapsi ei saa oman mielensä liikkeiden tueksi aikuisen antamia jäsennyksïa tilanteesta (Kääriäinen 2008b, 89-92).

Yhteisen keskustelun sijaan vanhemmat saattavat tarkkailla lastensa tunneilmaisuja ja käyttää niitä oman toimintansa suuntaamiseen ja vahvoihin tulkintoihin toisen vanhemman toiminnasta (Karttunen 2010,163). Lapsen ajatusten ja kokemusten välittäminen vanhemmille voi parhaassa tapauksessa pysäyttää vanhemmat pohtimaan omaa toimintaansa ja riitelyn vaikutuksia (Aaltonen 2015, 281). Huonossa tapauksessa vanhemmat ottavat lapsen sanomisen käyttöönsä omien tarkoitusperiensä tavoittelemiseksi ja toisen vanhemman mustamaalaamiseksi. Lapsen sanat tai tunteet ovat Karttusen $(2010,150)$ tut- 
kimustulosten mukaan monen konfliktin keskiössä. Lapsen kertomus tapahtumista tai tunteista toisen vanhemman luona voi aktivoida toisen vanhemman puolustamaan lasta. Karttunen tekeekin tärkeän havainnon siitä, kuinka lasten toiminnalla, ilmaisuilla ja mielipiteillä on merkitystä useimpien valitusprosessien aloittamisessa. Lasten sanomisia käytetään myös argumentteina toista vanhempaa vastaan. (Mt., 151.)

Useat tutkimukset (Aaltonen 2015; Ahrons 2006; Ballard ym. 2014; Quigley \& Cyr 2018;Vis \& Fossum 2013) nostavat esiin, että lasten kuuleminen eroprosessissa johtaa parempiin päätöksiin ja lapsille kuuleminen on tärkeä osa eroprosessia. Caroline Leeson $(2007,274)$ esittää, että usein lasten kanssa työskentelevät ammattilaiset kohtelevat lapsia haavoittuvina ja suojeltavina, mistä voi seurata, etteivät lapset pääse kertomaan tilanteesta omasta näkökulmastaan. Lapset kuitenkin tietävät omista tarpeistaan ja tunteistaan ja he ovat aktiivisia, ainutlaatuisia tiedontuottajia omasta tilanteestaan. Jopa vaikeissa eroriidoissa lapset haluavat sanoa omat käsityksensä edellyttäen, että heidän vanhempansa tukevat lasten osallistumista. (Quigley \& Cyr 2018, 523.) Suhtautuminen lapsiin tiedon tuottajina on yhä epäsystemaattista. Lapsia on esimerkiksi pidetty kyvykkäinä arvioimaan ja esittämään omia käsityksiään tilanteestaan silloin, kun he ovat olleet samaa mieltä aikuisten kanssa ja epäkypsinä silloin, kun lasten ja aikuisten näkemykset ovat ristiriidassa (Eriksson \& Nasman 2008).

\section{KiRJOITTAMISEN TODELLISUUTTA LUOVA LUONNE}

Asiakirjojen kirjoittaminen on tärkeä osa sosiaalityötä ja keskeinen taito sosiaalityöntekijöiden työssä (Brandt ym. 2011; Kääriäinen 2016; Roose ym. 2009). Asiakirjojen laadun ja tärkeyden korostamisesta on siirrytty yhä enemmän pohtimaan asiakkaiden mukaan ottamista asiakirjojen laadintaan (Kääriäinen 2003; Roose ym. 2009) sekä asiakirjojen merkitystä sekä päätöksenteossa (Kääriäinen 2016) että asiakkaiden omalle elämälle (Vierula 2017). Kirjoittamalla asiakirjoja asiakaskohtaamisista sosiaalityöntekijät puuttuvat asiakkaiden elämään ja tulevat määritelleeksi kohtaamiaan tilanteita ongelmallisiksi (Brandt ym. 2011). Ratkaisuksi tähän on kehitetty asiakkaita osallistavan dokumentoinnin käytäntöjä (esim. Roose ym. 2009), joskaan mitkään asiakirjojen laatimisen käytännöt eivät poista asiakirjan laatijan valtaa tehdä määrityksiä kuvatessaan tapahtumia.

Aiemmassa tutkimuksessani (Kääriäinen 2006) etsin ja löysin lasten puhetta lastensuojelun sosiaalityön asiakirjoista. Tuolloin lapsilähtöinen sosiaalityö oli nosteessa ja lapsen paikka tiedon tuottajana omasta tilanteestaan alkoi vahvistua (Tulensalo 2016). Tämän artikkelin aineiston lapsilla on lain suoma oikeus puhua ja kertoa käsityksiään olosuhdeselvityksen tekijöille, joilla on juridinen velvollisuus selvittää lapsen tilannetta ja näkemyksiä. Huoltoriidan yhteydessä lapsen kuuleminen tulee erityisen tärkeäksi, sillä tilanteessa voi piillä lapsen hyvinvointia uhkaavia riskejä (Roets ym. 2017). Ammatillisen arvion tekeminen ja sen kirjoittaminen asiakirjaan on merkityksellinen prosessi sekä 
lapsen ja vanhempien että työntekijän kannalta. Olosuhdeselvitysasiakirjan laatijan tehtävä on vaativa, sillä kirjoittaessaan kuvausta vanhempien ja lasten olosuhteista hän tulee määrittäneeksi, mikä on ongelmallista ja haitallista tai hyvää ja toivottavaa jo valmiiksi erimielisten vanhempien elämässä. Lapsen oikeuksia korostava ammattietiikka joutuu todelliseen koetukseen vanhempien huoltoriitojen keskellä, sillä lapsen puolelle asettuminen ja lapsen oikeuksien puolustaminen tarkoittaa lähes aina vanhempien oikeuksien jonkinasteista loukkaamista.

Asiakirjoilla on todellisuutta rakentava luonne, eivätkä kirjoittajat ja lukijat ole irti tästä todellisuudesta. Olennaiseksi tuleekin kysymys siitä, millä keinoin asiakirjassa voi välittää mahdollisimman oikeudenmukaisen ja todellisuutta kuvaavan esityksen kohtaamisesta. Tilanteen arviointiin on tarjolla standardoituja kyselyitä, tarkastuslistoja ja lomakkeita, joiden avulla työskentelystä tulee rationaalista ja työntekijä voi osoittaa keränneensä tarvittavaa tietoa, mikäli jokin menisi ei-toivottuun suuntaan (Roets ym. 2017). Toisaalta sosiaalityössä on paljon ilmiöitä, tilanteita tai asioita, joita voi olla mahdotonta suoraan havaita tai saada niistä varmaa tietoa. Tästä johtuen asiakirjojen kirjoittaminen tulisi Griet Roetsin ja kirjoittajakumppaneiden (2017, 464) mukaan nähdä ennemmin tarinan kertomisen käytäntönä kuin totuuden kertomisena. Tähän näkemykseen voi yhtyä, sillä asiakaskohtaamisista laaditut tekstit ovat aina vain viitteellisiä kuvauksia todellisista tapahtumista, jolloin autenttisuuden tavoittelu voi johtaa epäloogisiin ja pirstaleisiin muistiinmerkintöihin.

\section{SELVITySPROSESSI, AINEISTO JA ANALYYSI}

Tutkimuksen aineisto käsittää 56 olosuhdeselvitystä 45 tapauksesta vuodelta 2011. Aineisto on kerätty viidestä eri käräjäoikeudesta ja se on osin valikoitunut käräjäoikeuksien toimesta. Suomessa perheoikeudellisia päätöksiä tekeviä oikeusistuimia oli aineiston kokoamisen ajankohtana 27. Valitsemissani viidessä käräjäoikeudessa on mukana sekä pieniä, keskisuuria että suuria käräjäoikeuksia eri puolilta Suomea. Aineiston tapausten valikoinnin kriteerinä oli olosuhdeselvitys avioeron yhteydessä - ei tapauksen riitaisuus. Aineiston olosuhdeselvityksiä on laadittu 33 paikkakunnalla. Pienemmät käräjäoikeudet lähettivät kaikki muut olosuhdeselvitykset paitsi ne, joissa oli valitusprosessi kesken korkeimmissa oikeusasteissa tai jotka olivat muutoksenhaun kohteena. Keskisuuret ja suuret käräjäoikeudet lähettivät asiakirjat aineistopyyntöni lukumäärän (10-15 tapausta) mukaisesti. Tämä seikka yhdessä käräjäoikeuksin tekemän valikoinnin kanssa aiheuttaa aineistoon mahdollisia vinoumia ja rajaa siitä tehtäviä tulkintoja. Laadullisen analyysin tekemiseen aineisto on kuitenkin laaja käsittäen yhteensä 1488 asiakirjakopiosivua, josta sosiaalitoimen lausuntojen osuus on 496 sivua.

Lapsen mielipiteen selvittäminen tehdään tämän aineiston valossa systemaattisesti, sillä vain kymmeneen tapaukseen ei oltu kirjoitettu lapsen tapaamisesta tai lapsen kerrontaa johtuen ilmeisesti lapsen iästä (lapset iältään $6 \mathrm{kk}-5$ vuotta). Tällaisissa tapauksissa vanhempien toiminta lapsen kanssa ja työntekijöiden vaikutelma lapsesta oli kirjoitettu asiakirjaan. Lapsen tilanne oli joissakin 
tapauksissa arvioitu sen kaltaiseksi, että lapsen aidon mielipiteen selvittäminen oli epävarmaa johtuen vanhempien välisestä voimakkaasta erimielisyydestä, minkä oli arvioitu heijastuvan lapseen psyykkisenä oireiluna.Tähän artikkeliin aineistosta on erotettu lapsen kuulemiseen ja puheeseen keskittyviä kohtia, joita löytyi yhteensä 52 sivua (rivinväli 1, Gambria 11).

Analysoin lapsen kuulemisesta kirjoitettuja katkelmia tulkittuna käytäntönä (Gubrium \& Holstein 1997, 115). Analyysissä olen ensin erottanut aineistosta katkelmat lapsen raportoidusta kuulemisesta kysyen mitä ja miten lapsen kuulemisesta on kirjoitettu (analytic bracketing) (Gubrium \& Holstein 1997, 118-119). Käytännössä tämä tarkoitti sitä, että erotin, jaottelin ja ryhmittelin aineistokatkelmia etsien niistä rakenteellisia samankaltaisuuksia, joita kutsun kielen käytön rakenteiksi. Lapsen kuulemisesta kirjoittamisessa käytettiin pääsääntöisesti lapsen toiminnan havainnoinnista kirjoitettuja kuvauksia, keskusteluista rakennettuja dialogeja sekä lojaliteettiristiriidan ja turvattomuuden kuvaamista.

Selvityksissä on esitetty yksityiskohtaisesti, millaisiin tapaamisiin ne perustuvat, ketkä tapaamisiin osallistuivat ja kuinka monta kertaa asianosaisia tavattiin. Aineistossa huoltoriidan kohteena olevia lapsia oli kaikkiaan 71, joista poikia oli 41 (58 \%) ja tyttöjä 30 (42 \%). Pääsääntöisesti kaikkia osapuolia tavattiin selvitystyöskentelyssä mahdollisimman tasapuolisesti ja samankaltaisin järjestelyin. Lapsia tavattiin yksin ilman vanhempiaan 17 tapauksessa. Selvityksiin on dokumentoitu lapsen kuulemisen käytäntöjä sekä tapaamisissa käytet- tyjä menetelmiä ja välineitä sekä lapsen tiedollista toimijuutta vahvistavia tapoja, joita on viime vuosina kehitetty (esim. Hyvärinen \& Pösö 2018; Tulensalo 2016). Tutkimissani selvityksissä käytettiin haastatteluiden tukena usein erilaisia tunnekortteja, lauseen täydennystehtäviä, lomakkeita ja verkostokartan piirtämistä.

Vanhempien osallisuus lasten tapaamiseen on myös kuvattu, ja asiakirjoihin on toisinaan kirjoitettu vanhempien antama lupa lapselle puhua perheen asioista. Useimmat vanhemmat ovat kannustaneet lapsia kertomaan ajatuksiaan ja tukeneet heitä. Asiakirjoissa on myös kuvauksia siitä, että vanhemmat ovat estäneet lasten tapaamisen lasten esitettyä omia näkemyksiään tilanteestaan vanhempien riidan keskellä. Lapsia on myös pyydetty soittamaan sosiaalityöntekijöille kuulemista seuraavana päivänä ja korjaamaan mielipidettään vanhemmalle edullisemmaksi. Asiakirjoissa on todettu myös, että kaikki lapset eivät halunneet puhua selvityksen tekijöille, mutta halusivat kuitenkin osallistua sisarustensa kanssa tapaamiseen ja vastasivat kysymyksiin päätä nyökyttämällä "kyllä" tai päätä pyörittämällä "ei". Osassa teksteistä lapsen työskentelyä kuulemisessa kuvattiin keskittyneeksi ja lasten kerrottiin myös tehneen korjauksia, kun heidän kertomansa asiat käytiin läpi tapaamisen lopussa.

Lasten kuulemisesta kirjoitetuissa osuuksissa toistuvat teemat lapsen harrastuksista ja leikeistä, koulun käynnistä, asumisen järjestelyistä vanhempien luona (ks. myös Forberg ym.; Rissanen ym. 2017), vanhempien tapaamisen järjestelyistä, ruokailusta ja kodin askareista sekä lapsen läheisverkostosta. Näiden 
teemojen avulla on pyritty selvittämään lapsen näkemyksiä vanhempien huoltoriidan vaikutuksista ja merkityksistä lapsen elämään sekä lapsen toivomuksia asioiden järjestämiseksi.

Olosuhdeselvitykset ovat niin sanottuja luonnollisia, ilman tutkijan myötävaikutusta syntyneitä tekstejä. $\mathrm{Ne}$ kuvaavat sitä todellisuutta, jollaisena olosuhdeselvityksen prosessi on haluttu kuvata. Tekstit itsessään eivät kuvaa tehtyä työtä vaan sitä, mitä siitä on kirjoitettu (Kääriäinen 2003). Tässä artikkelissa tutkimuksen kohteena ovat lasten kuulemisesta kirjoittamisen tavat. Olosuhdeselvitystekstit ovat salassa pidettäviä ja näin ollen niiden käsittelemisessä on noudatettava erityistä huolellisuutta. Asiakirjojen tutkimuksessa tutkijoilla on aina eettinen velvoite tehdä oikeutta tutkimilleen ihmisille - tässä tapauksessa asiakirjojen laatijoille ja myös asianosaisille, joita asiakirjat kuvaavat.

Tulokset esitetään analysoimalla aineistosta tunnistettua kolmea kielenkäytön rakennetta. Käytän aineistolainauksia havainnollistamaan analyysin tuloksia. Olen poistanut katkelmista tunnistamisen mahdollistavat tiedot sekä merkinnyt numerolla, mihin tapaukseen katkelma liittyy ja minkä ikäinen lapsi on tekstin kirjoittamisen hetkellä (esim. 55, 6 v). Käytän isoa alkukirjainta, kuten Lapsi, Äiti, Isä ja Paikka silloin, kun tekstissä mainitaan kyseisen henkilön tai paikan nimi.

\section{LAPSEN TOIMINNASTA KIRJOITTAMINEN}

Lapsen tilanteen ja olosuhteiden selvittäminen tehtiin yleensä kummankin vanhemman kotona sekä joissakin ta- pauksissa työntekijöiden erikseen varaamassa tapaamistilassa. Lapsen tapaaminen alkoi ensin yhdessä vanhempien kanssa tutustuen. Asiakirjoissa selvityksen tekijät kuvasivat lapsen toimintaa ja vuorovaikutusta vanhempansa kanssa. Erityisesti läheisyydestä, kontaktin hakemisesta ja puhetavasta kirjoitettiin havaintoja sekä äidin että isän tapaamisen yhteydessä, mitä seuraavat katkelmat samasta tapauksesta havainnollistavat:

\section{Esimerkki 1.}

Isän luokse tehdyn kotikäynnin yhteydessä vaikutti siltä, että lapsen ja isän suhde on läheinen, luottavainen ja sopuisa. Lapsi hakeutui keskustelun aikana spontaanisti isän viereen eikä esille tullut minkäänlaista hankaluutta tai vaivautuneisuutta. Lapsi kertoi avoimesti ja runsaasti elämästään isänsä luona sekä koulun käymisestä. Lapsen puhe kuulosti varsin kypsältä 8-vuotiaan puheeksi. $(8,8 \mathrm{v})$

Lapsi hakeutui spontaanisti äidin lähelle ja syliin eikä kontaktiin näyttänyt liittyvän pakottamista tai vastahakoisuutta. Lapsi kertoi avoimesti asioistaan ja kuvasi olemistaan äidin luona varsin hyvin. Puhetavassa oli kenties havaittavissa enemmän lapsenomaisuutta kuin isän luona lasta tavattaessa. $(8,8 \mathrm{v})$

Selvityksiin oli kirjoitettu vertailuja lapsen toiminnasta kummankin vanhempansa luona eli siitä, miten lapsen käytös poikkesi eri tilanteissa ja ympäristöissä. Vanhempien välisessä huoltoriidassa osapuolet kertovat selvityksen tekijöille omia käsityksiään toisen vanhemman tavasta olla vanhempi, lapsen huomioimisen tavoista ja kyvykkyy- 
destä vanhemmuuteen (ks. myös Karttunen 2010). Selvityksen tekijöiden ja lapsen sekä vanhemman kohtaaminen muodostuu tilanteeksi, jossa aiemmin saatua informaatiota sovitetaan yhteen kohtaamisista tehtyjen havaintojen kanssa.

Havainnot vanhemman toiminnasta lapsensa kanssa, vanhemman kyky ohjata ja tukea lasta sekä lapsen hakeutuminen vanhemman läheisyyteen toistuivat lapsen kuulemisesta laadituissa kuvauksissa. Lapsen toimintaa vanhemman kanssa ja vanhemman kykyä asettaa lapselle rajoja oli kuvattu useasti, mitä esimerkki 2 havainnollistaa:

Esimerkki 2.

Lapsen ja äidin välinen vuorovaikutus oli vaihtelevaa. Välillä Lapsi upposi omaan tekemiseensä niin ettei hän kuullut, vaikka äiti esitti hänelle kysymyksiä. Leluja esitellessään Lapsi pyysi äitiään avuksi barbien hiusten selvittämisessä. Fyysistä kontaktia ei äidin ja lapsen välillä ollut. Lapsi pysytteli omissa oloissaan ja välillä kävi hakemassa kahvipöydästä keksejä tai esittelemässä askartelemaansa kirjaa. Lapsi tahtoi pelata äidin tietokoneella ja tämän äiti kielsi. Lapsi pyysi saada pelata uudemman kerran, mutta lopulta hän uskoi, kun äiti sanoi, ettei tietokonetta nyt oteta esiin. $(55,6 \mathrm{v})$

Asiakirja-aineistossa lapsen kuulemiseen liittyi olennaisesti lapsen toiminnan havainnointi vanhempiensa kanssa erityisesti pienten lasten kohdalla. Vanhemman ja lapsen välinen hyvä suhde on tutkimusten mukaan (esim. Nielsen 2017, 228) merkityksellisempi lapsen hyvinvoinnille kuin vanhem- pien sovinnollisuus eron jälkeen ja tähän kiinnitettiin runsaasti huomiota myös olosuhdeselvitysteksteissä. Lapsen ja vanhemman välistä suhdetta ja sen laatua tarkkailtiin ja siitä kirjoitettiin kuvauksia, joiden yksityiskohtaisuus ja dokumentaarisuus vakuuttavat lukijaa.

\section{RAKENNETTUJEN DIALOGIEN LAATIMINEN}

Tilanteiden ja tapahtumien toistaminen asiakirjakontekstissa muuttaa aina niiden luonnetta ja merkitystä, sillä kerrotusta tulee kirjoittajan esittämä luomus. Asiakastyöstä kirjoitetuissa asiakirjoissa käytetään hyvin yleisesti tapaa kirjoittaa suoria lainauksia eri osapuolien puheesta (esim. Kääriäinen 2003; 2006). Sitaattien käyttäminen ei ole kuitenkaan välttämätöntä puheen esittämiseksi. Dialogin rakentaminen tekstiin on kertomisen tavan valinta (Tannen 2007) siinä missä muutkin tekstin laatimisen valinnat. Asiakirjassa puheenvuorojen lainaukset esitetään osapuolelle, joka ei ole ollut keskustelussa läsnä. Dialogin rakentaminen asiakirjassa ei useinkaan tarkoita kirjaimellista toisen sanomisen kuvaamista. Rakennetun dialogin käyttäjä raportoi ilmauksia usein osin muistinvaraisesti ja epätarkasti tai intentionaalisuuden tavoittaen, vaikka lauseiden mieli, luonne ja sävy ovat muokattuja. (Kandel 1994, 898-899.)

Lapsen äänen ja mielipiteen kertomiseen asiakirjassa käytettiin hyvin yleisesti rakennettuja dialogeja, joissa osallistujien puheet oli taltioitu lainausmerkein kuvaamaan tilanteessa käytyä vuoropuhelua. Rakennetut dialogit luovat vahvan kuvauksen puhujan (kirjoittajan) ja 
kuulijan (lukijan) välille, sillä ajatusten ja puheen roolijako luo yksityiskohtaisia kuvauksia ja henkilöhahmoja. Ne kutsuvat lukijan osallistumaan tarinaan. (Kandel 1994, 898-899.) Seuraava esimerkki 3 havainnollistaa tätä kirjoittamisen tapaa:

\section{Esimerkki 3.}

Isä totesi Lapselle, että tämä voi pian tulla isän luo yökylään, "siellä on sun sänky". "Miksi? En halua" totesi lapsi. "Jos kerran olet ja rupeet tykkään" vastasi isä. "Äiti joutuu oleen [Paikkakunnalla]" totesi Lapsi. Puutuimme keskusteluun toteamalla Lapselle, että "mitä jos äiti sanookin, että on ok mennä isälle yökylään"- "No, mä en tykkää" sanoi Lapsi. "Äiti voi olla [Tädin] luona" ehdotti isä. "Ei se aina voi olla" vastasi Lapsi tähän. "No se on kyllä totta” myönsi isä. Lapsen ja isän keskustelu siirtyi Lelujen röntgenkatseeseen. [...] Isä kehotti lasta välillä jatkamaan leivän ja viilin syömistä. Lapsi nojaili isän kylkeen ja isä kysyi tältä "nukuitko tänään päiväunet". Lapsi totesi, ettei ole nukkunut. Isä nosti lapsen syliinsä. Isä kyseli lapselta väreistä: mikä on punaisen väristä, mikä on valkoista ja Lapsi keksi helposti vastauksia. Lapsi ja isä keskustelivat nukkumatista ja joulupukista ja Lapsi halusi tietää, mistä nukkumatti pääsee sisään asuntoihin. Lapsi kysyi, miksi isä asui kerrostalossa ja miten hänen huoneensa mahtuu sinne. "Kuule sulla on hieno huone siellä" totesi isä. $(38,5 \mathrm{v})$

Käyttämällä kirjoitustekniikkana osallistujien vuoropuhelua ja ilmaisemalla vuorosanat lainausmerkein, tekstin laatija luo autenttisen ja riidattoman tapahtumakuvauksen. Dialogien kirjoit- taminen asiakirjaan on potentiaalinen väline rakentaa eri osapuolien toimijuuksia sekä jakaa vastuuta kirjoittajan ja lukijan välillä. Kun tekstiin on liitetty puheenvuorojen välille kertovaa kuvausta, lukijan on helppo seurata tapahtumakulkua. Kirjoitustekniikka tuo vakuuttavasti esiin lapsen oman äänen kuulemisen ja tilanteen käsittämisen.

Seuraavassa katkelmassa (esimerkki 4) kirjoittaja on valinnut myös dialogisen esittämisen tavan, mutta tallentanut pelkästään lapsen kertomat lauseet peräkkäin erillisinä lainausmerkein erotettuina lauseina:

\section{Esimerkki 4.}

Kun Lapselta kysyttiin, millainen isä hänellä on, niin hän vastasi "Isi puuttuu", "Mulla ei ole enää isiä". "Haluan uuden isin". "Äiti etsii ja etsii uutta isiä". "Mulla oli huono olla isin kanssa." "Isi löi mua ja se täti (isän avovaimo) löi mua”. "Isi kaato puurot mun pälle, mä jouduin menee likaisella puserolla eskariin" "Se (isä) ei antanut äidille viestiä, että hyvää synttäriä sun lapselle." ”Mä tahdon sellaisen isin, joka antaa rahaa äidille ja jolla on auto." 'Joka tykkää ja huolehtii lapsista." (52, 9 v)

Katkelman välittämästä informaatiosta syntyy fragmentaarinen tilannekuvaus, eikä lapselle esitettyjä mahdollisia kysymyksiä ole kirjoitettu näkyviin. Lapsen ääni on talletettu asiakirjaan, mutta sen välittämän informaation tulkinta on jätetty lukijalle. Käyttämällä rakennettua dialogia kirjoittaja voi käsitellä kirjoittajan valtaansa suhteessa omaan ääneensä tai päästä eroon vastuusta julkituoduista asioista (Kandel 1994, 900). Kirjoittamalla lapsen kertomat lauseet 
erillisiksi, kirjoittaja välttyy tekemästä tulkintaa lapsen puheesta, mutta on kirjoittamisen valinnallaan tehnyt lukijalle mahdollisuuden tulkita tekstiä vapaasti.

Lainausmerkeillä halutaan korostaa puheen autenttisuutta, vaikka lainaukset ovat harvoin sanatarkkoja (Kandel 1994, 899). Puheen taltioiminen asiakirjaan ei kuitenkaan edellytä lainausmerkkien käyttöä, kuten esimerkki 5 havainnollistaa:

\section{Esimerkki 5.}

Lapsi kertoo, että isä kieltää häntä puhumasta asioista, joista luulee äidin haluavan haastaa riitaa. Hän kertoi esimerkkinä isän toivoneen, ettei äidille kerrottaisi hänen halunneen luututa isän luona, jotta päästäisiin nopeammin katsomaan dvdtä. Lapsi kertoi äidin olevan normaali äiti, mutta isä ei hänen mielestään ole normaali isä. Lapsi kertoi isällä olon huonoiksi puoliksi, että isän luona ei esim. iltapalalla saa syödä vatsaa täyteen ja isän luona on huono tyyny, jolla nukkua. Lapsi kertoi isän kysyvän tyhmiä kysymyksiä. Hän kertoi, että isä on kamala ja hänen täytyy olla isän luona seurana isälle. Lapsen mielestä hänen pitää olla isän kanssa asioista samaa mieltä. Hän kertoi isän määräävän melkein kaikesta. Lapsi ilmaisi pettymyksensä siihen, että isä ei kuuntele häntä. Hän kertoi isän tiuskivan ja pakottavan olemaan samaa mieltä. Lapsi kertoi kysyttäessä, mistä hän haluaisi isän luona päättää, että hän haluaisi sanoa näkemyksensä siihen, onko äiti ärsyttävä vai ei. $(23,8$ v)

Rakennettu dialogi on merkityksellistä erityisesti silloin, kun saadussa informaatiossa esiintyy toisen käden tietoa
(Kandel 1994, 900) eli tietoa, jonka kertoja kertoo jonkun toisen sanoneen tai tehneen. Niin sanotun toisen käden tiedon tai kuulopuheen avulla puhuja voi lisätä auktoriteetin painoa omaan puheeseensa tai siirtää vastuuta itseltä puhujalle. Kirjoittaja voi rakentaa tekstiin sisäisiä vuoropuheluita, jolloin lukija voi tehdä tulkintoja kerrotuista henkilöistä tekstiin luotujen "ikkunoiden" avulla. (mt., 901.) Edellä olevassa esimerkissä (esimerkki 5) on useita kohtia, joissa lapsi kertoo isän sanoneen, kieltäneen tai kysyneen jotakin. Kirjoittaja ei ole tallettanut näkyviin kaikkia lapselle tekemiään kysymyksiä, joita kuitenkin on pääteltävissä tekstistä. Selvityksen tekijä on ilmeisesti pyytänyt lasta tarkentamaan kertomaansa esimerkeillä, jolloin teksti vakuuttaa lukijaa yksityiskohtaisuudellaan, mutta ei rakenna lapsen kuulemisesta vuorovaikutuksellista kohtaamista. Tällöin lapsen kertoma jää lapsen vastuulle, ja myös se, miten isä toimii lapsen kanssa. Kirjoittaja on häivyttänyt oman osuutensa keskustelusta taustalle.

\section{LOJALITEETTIRISTIRIIDAN JA EMOTIONAALISEN TURVALLISUUDEN HAVAINNOLLISTAMINEN}

Eroavien vanhempien riitelyn keskelle joutuva lapsi kohtaa vastakkaisiin suuntiin vetäviä lojaaliuteen liittyviä sidoksia (Castrén 2018, 175). Molemmat vanhemmat ovat lapselle usein merkityksellisiä ja tärkeitä - kumpikin omalla tavallaan. Huoltoriidassa lapselta kuitenkin odotetaan ja vaaditaan mielipidettä asumiseen ja arkielämän järjestämiseen. Selvitysteksteissä lasten kertomana oli kuvattu tilanteita, joissa 
heidän ottaessa esiin toisesta vanhemmastaan hyviä asioita, syntyy lapsen ja vanhemman välille riitaa. Lapset myös kertoivat pahoittavansa mielensä siitä, että vanhempi haukkui toista vanhempaa lapselle (myös Kääriäinen 2008a; Notko \& Sevón 2018). Lapsen oman toiminnan tarkkailemisesta oli kirjoitettu toistuvasti lapsen kuulemisen yhteydessä, jota seuraava katkelma havainnollistaa:

\section{Esimerkki 6.}

Lapsi kertoo tapaamisen lopulla, että hän ei voi puhua surullisista ja mieltä painavista asioista kenellekään. Koulussa opettajalle tai terveydenhoitajalle voi puhua joistain asioista. Lapsen mielestä hänellä on helpompaa puhua toisista asioista äidille ja toisista isälle. Lapsi kertoo, ettei hän voi puhua äidin kuullen isästä. Hän kertoo, ettei aina huomaa puhuvansa ja sitten hän lopettaa. Isän luona hän on huomannut, että isä menee hiljaiseksi jos hän puhuu äidistä. Lapselle annettiin lopuksi kolme toivetta, joilla asiat olisivat hänen mielestään hyvin. Lapsi kertoo ensimmäisenä haluavansa olla enemmän iskän kanssa. Toisena toiveena Lapsella on, että äiti ei puhuisi isästä vihaisesti lasten kuullen. Lapsi kertoo hakeutuvansa muualle, kun äiti puhuu isästä. Lapselta pääsee itku hänen kertoessaan toivettaan. Lapsen mukaan isä puolestaan puhuu vain vähän äidistä ikäviä asioita. Kolmantena Lapsi toivoo, että äiti ei olisi isälle vihainen. $(24,8$ v)

Olosuhdeselvitysasiakirjoissa lapsen kuulemisesta on tallennettu toistuvasti episodeja, joissa on kuvattu lasten tunnekuormaa vanhempien riidellessä. Näillä kuvauksilla on havainnollistettu lasten elämäntilannetta ja vaikeutta säädellä omia sekä vanhempiensa välittämiä tunteita. Olosuhdeselvityksiin on talletettu lasten kuvauksia, joissa heille on annettu vaativa tehtävä päättää omasta asumisestaan. Seuraava esimerkki 7 kertoo tällaisesta tilanteesta:

\section{Esimerkki 7.}

Lapsi kertoi haluavansa tavata molempia vanhempiaan yhtä paljon ja hän sanoi kertoneensa toiveistaan myös vanhemmille. Isä oli Lapsen mukaan kommentoinut, että olisi parempi, jos Lapsi asuisi hänen kanssaan lähellä koulua. Äiti oli sanonut haluavansa Lapsen asuvan luonaan. Lapsi totesi lopuksi, ettei hän osaa vielä päättää, kumman luona hän haluaisi asua. Hän kertoi äidin ja isän sanoneen hänelle, että hän saa itse päättää. $(40,11$ v)

Lapsen kuvaus vanhempiensa erimielisyydestä asumisasiassaan ja toteamus, ettei lapsi itse osaa vielä päättää asumisestaan, on taltioitu asiakirjaan. Vanhemmat ovat kuitenkin antaneet hänelle päätösvallan, minkä kirjaamisella näkyviin asiakirjaan on kenties haluttu korostaa lapsen vaativaa tilannetta ja vanhempien kyvyttömyyttä toimia lapsen edun mukaisesti. Tulkitsen, että tällä on havainnollistettu lapsen kokemaa lojaliteettiristiriitaa vanhempien erossa. Aineistossa oli useita kohtia, joissa kuvattiin lasten vaikeuksia ymmärtää vanhempiensa sellaista toimintaa, joka näyttäytyy lapselle valheellisena ja epäjohdonmukaisena. Vanhempien erotessa muutokset perheessä voivat olla hyvin nopeatempoisia, eikä lapsille aina muisteta, ehditä tai ymmärretä kertoa riittävästi (Kääriäinen 2008a, 42-44). Vanhempien huoltoriidasta juontuvia lapsen turvattomuuden kokemuksia oli 
taltioitu asiakirjoihin useita, kuten seuraavassa esimerkissä 8:

\section{Esimerkki 8.}

Lapsi kertoo, ettei isä koskaan selittänyt sitä hänelle, miksi hänen asumistaan ja kouluaan muutettiin. Lapsi sanoo kysyneensä asiasta isältä, mutta isä ei suostunut kertomaan syytä. Lapsi kertoo, että hänellä oli kova ikävä ja huoli äidistä. Äidin sisar [Täti] auttoi Lasta jaksamaan eron äidistä. Pari kertaa Lapsi oli [Tädin] luona äidin soittaessa ja tuolloin hän sai puhua äidin kanssa puhelimessa. Lapsi kertoo, että hänen elämäänsä tuli uusi murhe, kun isä kielsi häneltä yön yli kestävät vierailut [Tädin] luona. Lapsi sanoi olevansa iloinen ja onnellinen kun sai muuttaa takaisin äidin luokse. $(45,10 \mathrm{v})$

Lapsen kuulemisesta laadituissa asiakirjateksteissä kuvataan, miten lapsen perusturvallisuuden tunne ja luottamus vanhempien toimintaan joutuvat koetukselle vanhempien huoltoriidassa. Emotionaalisen turvallisuuden (Davies ym. 2002) ja fyysisen turvallisuuden puuttumista havainnollistetaan selvityksissä sillä, että lapset kertovat pelkäävänsä vanhempansa vihastumista, huutamista ja lyömistä. Vanhempien ero ei ole yksittäinen merkityksellinen tekijä lasten hyvinvoinnille, vaan ennemminkin vanhempien kyky ylläpitää lapsen emotionaalinen turvallisuudentunne erosta huolimatta (Davies ym. 2002; Kääriäinen 2009; Notko \& Sevón 2018).Väkivallan kuvaukset ovat toistuvia lasten kuulemisen kuvauksissa. Usean lapsen kertomana toistui pelko, että lapsi ei pääsisi enää takaisin toisen vanhemman luokse. Seuraava esimerk- ki 9 kuvaa lapsen pelkoa vastentahtoisesta jäämisestä vanhemman luokse:

\section{Esimerkki 9.}

Tapaamisessa lapsi kertoo systemaattisesti, että hän pelkää, että joutuu jäämään äidin luokse, eikä pääse enāä isän luokse takaisin. $(28,10$ v.)

Vanhempien riitelystä aiheutuva turvattomuus tulee esiin monissa yhteyksissä lasten kuulemisista laadituissa asiakirjoissa. Vanhemman ja lapsen välisen suhteen laatu on tärkeä lapsen hyvinvointiin vaikuttava tekijä vanhempien erotessa (Autonen-Vaaraniemi 2018; Nielsen 2017; Sigurdardóttir ym. 2018). Kuvauksilla on tuotu esiin, kuinka vanhempien eron jälkeen lapsen ja vanhempien yhteisestä ajasta tulee erityistä, suunniteltua ja ohjelmoitua.Vanhempien riitaisat välit lisäävät tähän epäluottamusta, ennakoimattomuutta sekä pelkoa lupausten rikkoutumisesta.

\section{JOHTOPÄÄTÖKSET JA POHDINTA}

Lapsen mielipiteen kuuleminen olosuhdeselvitysprosessissa on tärkeä ja vaativa tehtävä. Olen analysoinut näistä kuulemisista kirjoitettuja tekstejä, joilla on oma erityinen juridinen tehtävänsä huoltoriidan ratkaisemisessa. Lapsen kuulemisen erottaminen asiakirjakokonaisuudesta on osin väkivaltainen teko, mutta toisaalta perusteltu, koska lapsen mielipiteen selvittäminen on merkityksellinen selvitysprosessin kokonaisuudessa. Asiakirjatekstit ovat aina tulkittuja ja sidoksissa kirjoittajansa tekemiin valintoihin. Olen rajannut näkökulmani siihen, millä tavoin lapsen kuulemisesta kirjoitetaan vanhempi- 
en huoltoriidassa. Lasten mielipiteiden kuunteleminen edellyttää myös vastuun ottamista siitä, mitä saadulla tiedolla tehdään, mihin tiedot vaikuttavat ja miten tietoa käytetään osana päätöksentekoprosesseja. Lapsi on huoltoriidan keskellä ja riitelyn kohde. Se, millä tavoin lapsen näkökulma esitetään, kertoo myös kirjoittajan asennoitumisesta lapsen tietoon. Kirjoittamisessa tehdyt valinnat vaikuttavat siihen, millaisena lapsen tilanne asiakirjoista välittyy.

Olosuhdeselvitysasiakirjoissa lapsen kuulemisesta oli kirjoitettu yksityiskohtaisia kuvauksia. Mitä yksityiskohtaisempia tekstit ovat, sitä paremmin ne luovat tilanteista toden tuntuisia (Perelman 1996, 31), mikä on näiden tekstien tarkoituksenakin. Lapsen kuulemisen kirjoittamisessa käytettiin pääasiassa lapsen toiminnan havainnointia, tekstiin rakennettuja dialogeja sekä lojaliteettiristiriidan ja turvattomuuden kokemusten havainnollistamista. Lapselle annetaan tekstissä erilaisia asemia ja vastuuta tiedosta. Tekstin rakentamisen valinnoilla kirjoittaja voi säädellä sitä, kuka tietoa kantaa: puhuja, kirjoittaja vai lukija. Rakennettujen dialogien käyttäminen vakuuttaa ja osallistaa lukijan kerrottuun (Kandel 1994), mutta toisaalta dialogien kirjoittamisella selvityksen laatija voi myös ottaa etäisyyttä kerrottuun ja siirtää lukijalle vastuun tulkinnan tekemisestä.

Olosuhdeselvityksen laatijalla on vastuu lapselta saadun tiedon välittäjänä, sillä lapsen mielipiteen kirjoittaminen näkyviin saattaa lisätä vanhempien konfliktoituneita suhteita (esim. Karttunen 2010, 150) ja olla siten seurauksellista myös lapselle. Lasten lojaliteettiristiriidan ja turvattomuuden kokemusten esiin tuomisessa kaiken kuulemansa ja näkemänsä kirjoittaminen voi johtaa lapsen näkökulmasta pahimmillaan vanhempien lisääntyvään riitelyyn. Parhaimmillaan vanhemmat saavat nähdäkseen lapsensa tarkkaa analyysï vanhemmuudestaan. Linda Nielsenin $(2017,228)$ mukaan eroriidan ei pitäisi olla määräävä tekijä lapsen huoltajuudesta tai asumisratkaisuista päätettäessä, paitsi silloin, kun lapset tarvitsevat suojelua alistavien tai välinpitämättömien vanhempien kohtelulta. Analysoimani lapsen kuulemisen kuvaukset tuovat esiin, kuinka lapset elävät vanhempiensa huoltoriidan keskellä tilanteissa, joissa vanhemmat eivät aina kykene toimimaan lapsensa parhaaksi.

Huoltoriitojen oikeudellisen ratkaisemisen yhteydessä laaditut olosuhdeselvitykset sisältävät kiinnostavan otoksen lasten puheesta ja kerronnasta sekä vanhempien suhtautumisesta lastensa kuulluksi tulemiseen. Ne osoittavat, että pienten lasten kyvyt havainnoida aikuisten keskusteluja ja omaa puhettaan ovat varsin kehittyneitä (myös Nikupeteri \& Laitinen 2017). Lapsen äänen kirjoittaminen asiakirjaan on vastuullinen tehtävä. Kirjoittaja joutuu tasapainoilemaan autenttisuuden, eettisyyden ja seurauksellisuuden välillä. Oikeudellisen päätöksentekoprosessin näkökulmasta käyttökelpoinen teksti ei välttämättä auta riidan ratkaisemisessa tai palvele lapsen etua.

Huoltoriidat kytkeytyvät yhteiskunnassa vallitseviin arvoihin ja asenteisiin (Auvinen 2002, 129). Lapsen osallisuutta korostavan asenneilmapiirin vahvistuminen voi ennustaa nykyistä parempaa lapsen huomioimista palveluissa ja lasta koskevien ratkaisujen tekemisessä. Lasten kuuleminen on 
tärkeä osa eroprosessia (Ballard ym. 2014, 19), sillä se auttaa sekä vanhempia että viranomaisia tekemään lapsen edun mukaisia ratkaisuja ja lisää lasten voimavaroja ymmärtää tilannetta. Katseen kääntäminen nykyistä vahvemmin riitelyn seurausvaikutuksiin lapsen elämässä olisi olennaista.

\section{VIITE}

${ }^{1}$ Kiitos Alli Paasikiven säätiölle rahoituksesta vuosina 2012 ja 2014 tutkimushankkeelleni "Äitien, isien vai lasten puolella? Tekstien sukupuolisuus sosiaalitoimen olosuhdeselvityksissä”.

\section{KirJallisuUs}

Aaltonen, Anna-Kaisa (2015) Huoltoriitojen sovittelu tuomioistuimessa. Helsinki: Kauppakamari.

Ahrons, Constance R. (2006) Family Ties After Divorce: Long term Implications for Children. Family Process, 46 (1), 53-65. https://doi.org/10.1111/j.15455300.2006.00191.x

Alanen, Leena (2009) Johdatus lapsuudentutkimukseen. Teoksessa Leena Alanen \& Kirsti Karila (toim.) Lapsuus, lapsuuden instituutiot ja lasten toiminta. Tampere: Vastapaino, 9-30.

Alatalo, Marjo \& Lappi, Kari \& Petrelius, Päivi (2017) Lapsikeskeinen suojelu ja perheen toimijuuden tukeminen lastensuojelun perhetyössä ja perhekuntoutuksessa: Kohti monitoimijaista, yhteistä perhetyötä. Työpaperi 21. Helsinki: Terveyden ja hyvinvoinnin laitos.

Autonen-Vaaraniemi, Leena (2018) Vanhempien riidat vuoroasuvien lasten näkökulmasta. Teoksessa Hannele Forsberg \& Aino Ritala-Koskinen (toim.) Monen kodin lapset. Lasten monipaikkainen asuminen ja sosiaalityö. Helsinki: Gaudeamus, 52-73.

Auvinen, Maija (2002) Huoltoriita ja sosiaalitoimi. Teoksessa Marjukka Litmala (toim.) Lapsen asema erossa. Helsinki: WSOY, 112-168.

Auvinen, Maija (2006) Huoltoriidat tuomioistuimissa: sosiaalitoimi selvittäjänä, sovittelijana, asiantuntijana. Helsinki: Suomalainen lakimiesyhdistys.

Ballard, Robin H. \& Rudd, Brittany N. \& Applegate, Amy G. \& Holzworth-Munroe, Amy (2014) Hearing the Voice of the Child in Divorce. Teoksessa Monika K. Miller, Jared Chamberlain \& Twila Wingrove. Psyhology, Law, and the Wellbeing of Children. Oxford Scholarship Online. Oxford University Press, 1-27. https://doi.org/10.1093/acprof:o so/9780199934218.003.0008

Brandt, Lieve \& Roose, Rudi \& BouverneDe Bie, Maria \& De Schyver, Maarten (2011) Data recording and social work: From the relational to the social. British Journal of Social Work 41 (7), 13721382. https://doi.org/10.1093/bjsw/ bcr131

Castrén, Anna-Maija (2018) Lojaaliuden vaativat sidokset. Teoksessa Petteri Eerola \& Henna Pirskanen (toim.) Perhe ja tunteet. Helsinki: Gaudeamus, 165-181.

Cukurs, Minna (2018) Lapsi näkyväksi. Lastensuojelun avohuollon asiakaslasten oikeudet eroriitojen varjossa. Pro gradu -tutkielma. Helsingin yliopisto, Valtiotieteellinen tiedekunta.

Davies, Patrick T. \& Harold, Gordon T. \& Goeke-Morey, Marcie C. \& Cummings, E. Mark (2002) Child emotional security and interparental conflict. Monographs of society for research in child development. Serial No. 270, 67 (3). Boston: Blackwell Publishing. https:// doi.org/10.1111/1540-5834.00208

Eriksson, Maria \& Nasman, Elisabeth (2008) Participation in family law proceedings for children whose father is violent to the mother. Childhood 15 (2), 259-277. https://doi. org/10.1177/0907568207088426

Forsberg, Hannele \& Kääriäinen, Aino \& Ritala-Koskinen, Aino (2018) Children's residencein divorce disputes - examination of social work reports to the court, Journal of Social Welfare and Family law, 40 (1), 21-36. https://doi.org/10.1080/ 09649069.2018.1414351

Gubrium, Jaber F \& Holstein, James A. 
(1997) The new language of qualitative method. Oxford: Oxford University Press.

Hautanen, Teija (2010) Väkivalta ja huoltoriidat. Acta Elektronica Universitatis Tamperensis 989. Tampere: Tampere University Press.

HE 88/2018. Hallituksen esitys eduskunnalle laiksi lapsen huollosta ja tapaamisoikeudesta annetun lain muuttamisesta ja eräiksi siihen liittyviksi laeiksi.

Hyvärinen, Sauli \& Pösö, Tarja (toim.) (2018) Lasten haastattelu lastensuojelussa. Jyväskylä: PS-kustannus.

Kandel, Randy Frances (1994) Power Plays: A Sociolinguistic Study of Inequality in Child Custody Mediation and a Hearsay Analog Solution, Arizona Law Review 36 (4), 879-972.

Karttunen, Risto (2010) Isän ja äidin välissä. Lapsen kuulemisen psykologinen kehys huolto- ja tapaamisriidoissa. Acta Universitatis Tamperensis 1546. Tampere: Tampere University Press.

Koulu, Sanna (2014) Lapsen huolto- ja tapaamissopimukset. Helsinki: Lakimiesliiton kustannus.

Kääriäinen,Aino (2003) Lastensuojelun sosiaalityö asiakirjoina. Dokumentoinnin ja tiedonmuodostuksen dynamiikka. Helsinki: Helsingin yliopisto.

Kääriäinen, Aino (2006) Lapset sosiaalityön asiakasdokumenteissa. Teoksessa Hannele Forsberg, Aino Ritala-Koskinen \& Maritta Törrönen (toim.) Lapset ja sosiaalityö. Kohtaamisia, menetelmiä ja tiedon uudelleen arviointia. Jyväskylä: PS-kustannus, 45-67.

Kääriäinen, Aino (2008a) Lasten auttaminen vanhempien erotessa. Teoksessa Sirkku Niemelä \& Aino Kääriäinen. Millan isä ja äiti eroavat - miten lasta voi auttaa vanhempien erotessa. Helsinki: Suomen Kasvatus- ja perheneuvontaliitto ry, 3649. https://doi.org/10.33350/ka.79826

Kääriäinen, Aino (2008b) Lasten tukeminen Taikuri-ryhmissä. Teoksessa Sirkku Niemelä \& Aino Kääriäinen. Millan isä ja äiti eroavat - miten lasta voi auttaa vanhempien erotessa. Helsinki: Suomen Kasvatus- ja perheneuvontaliitto ry, 6894. https://doi.org/10.33350/ka.79826

Kääriäinen, Aino (2009) Ero haastaa vanhemmuuden. Neuvo-projektin julkaisu- ja. Helsinki: Lastensuojelun Keskusliitto.

Kääriäinen, Aino (2015) Sosiaalitoimen olosuhdeselvitykset teksteinä - Johtopäätösten argumentointi ja puolelle asettumisen tulkinnat. Oikeus 44 (4), 379-403.

Kääriäinen, Aino (2016) Sosiaalityön dokumentointi: suhde tietoon ja toimintaan. Teoksessa Maritta Törrönen, Kaija Hänninen, Päivi Jouttimäki, Tiina LehtoLundén, Petra Salovaara \& Minna Veistilä (toim.) Vastavuoroinen sosiaalityö. Helsinki: Gaudeamus, 189-197.

Lastensuojelun käsikirja THL (2019) https://thl.fi/fi/web/lastensuojelun-kasikirja Luettu 12.1.2019.

Leeson, Caroline (2007) My life in care: experiences of non-participation in decision-making processes. Child and Family Social work 12 (3), 268-277. https://doi. org/10.1111/j.1365-2206.2007.00499.x

LHL, Laki lapsen huollosta ja tapaamisoikeudesta 361/1983.

Nielsen, Linda (2017) Re-examining the research on parental conflicts, coparenting and custody arrangements. Psychology, Public Policy and Law 23 (2), 211-231. https://doi.org/10.1037/ law0000109

LOS, Lapsen oikeuksien yleissopimus (1991) SopS 60/1991, Yhdistyneet kansakunnat.

Nikupeteri, Anna \& Laitinen, Merja (2017) Lasten sensitiivisten kokemusten tutkimisen metodologiset valinnat - Esimerkkinä vanhempien välisen eron jälkeisen vainon tutkimusprosessi. Kasvatus \& Aika 11 (1), 6-23.

Notko, Marianne \& Sevón, Eija (2018) Konfliktit lasten perhesuhteissa. Teoksessa Petteri Eerola \& Henna Pirskanen (toim.) Perhe ja tunteet. Helsinki: Gaudeamus, 67-87.

Oikeusministeriö (47/2017) Lapsenhuoltolain uudistaminen. Työryhmän mietintö.

Perelman, Chaïm (1996[1977]) Retoriikan valtakunta. Tampere:Vastapaino.

PL, Suomen perustuslaki 731/1999.

Quigley, Catherine \& Cyr, Francine (2018) The Voice of the Child in Parenting Coordination: Views of Children, Parents, and Parenting Coordinators. Journal of Divorce \& Remarriage 59 (6), 501-527. https://doi.org/10.1080/10502556.201 


\subsection{3}

Ricœur, Paul (2000 [1976]) Tulkinnan teoria. Diskurssi ja merkityksen lisä. Helsinki: Tutkijaliitto.

Rissanen, Antti \& Kääriäinen, Aino \& Rantala, Kati \& Sarasoja, Laura \& Aikio, Marjut (2017) Vuoroasumisesta sopiminen ja periaatteet vanhempien ja viranomaisten käsityksinä. Janus 25 (1), 38-56.

Roets, Griet \& Roose, Rudi \& De Wilde, Liselot \& Vanobberger, Bruno (2017) Framing the 'child ant risk' in social work reports: Truthtelling or storytelling? Journal Social Work 17 (4), 453-469. https://doi. org/10.1177/1468017316644864

Roose, Rudi \& Mottart, Andre \& Dejonckheere, Nele \& van Nijnatten, Carol \& De Bie, Maria (2009) Participatory social work and report writing. Child and Family Social Work 14 (3), 322330. https://doi.org/10.1111/j.13652206.2008.00599.x

SHAL, Laki sosiaalihuollon asiakkaan asemasta ja oikeuksista 812/2000.

Sigurdardóttir, Sólveig \& Júlíusdóttir, Sigrún \& Pálsdóottir, Dögg (2018) Children's voices on equal time-sharing arrangement following parents' divorce. Journal of Social Welfare and Family Law 40 (2), 164-180. https://doi.org/10.108 0/09649069.2018.1446710

Simon, Robert A. \& Stahl, Philip M. (2014) Analysis in child-custody reports: A crucial component. Family Law Quarterly 48 (1), 35-51.

Skjørten, Kristin (2013) Children's voices in Norwegian custody cases. International Journal of Law, Policy and the Family 25 (3), 289-309. https://doi. org/10.1093/lawfam/ebt011
SVT, Suomen virallinen tilasto (2017) Lapsen elatus ja huolto sekä isyyden selvittäminen. Helsinki: Tilastokeskus. https://thl.fi/fi/tilastot-ja-data/tilastotaiheittain/lapset-nuoret-ja-perheet/ lapsen-elatus-ja-huolto. Luettu 2.1.2019. https://doi.org/10.14214/sf.a14097

Tannen, Deborah (2007) Talking voices Repetition, dialogue, and imagery in conversational discourse. Cambridge: Cambridge University Press. https://doi. org/10.1017/s004740450001633x

Taskinen, Sirpa (2001) Lapsen etu erotilanteessa. Opas sosiaalitoimelle. Oppaita 46. Helsinki: Stakes.

Tulensalo, Hanna (2016) Lapsi tiedollisena toimijana lastensuojelun sosiaalityössä. Teoksessa Mirja Satka, Ilse Julkunen, Aino Kääriäinen, Ritva Poikela, Laura Yliruka \& Heidi Muurinen (toim.) Käytäntötutkimuksen taito. Helsinki: Heikki Waris -instituutti ja Mathilda Wrede Institutet, 262-288.

Vierula, Tarja (2017) Lastensuojelun asiakirjat vanhempien näkökulmasta. Acta Universitatis Tamperensis 2323. Tampere: Tampere University Press.

Vis, Svein Arild \& Fossum, Sturla (2013) Representation of children's views in court hearings about custody and parental visitations - A comparison between what children wanted and what the courts ruled. Children and Youth Services Review 35 (12), 2101-2109. https://doi. org/10.1016/j.childyouth.2013.10.015 